\title{
DROUGHT-INDUCED EFFECTS AND RECOVERY OF NITRATE ASSIMILATION AND NODULE ACTIVITY IN COWPEA PLANTS INOCULATED WITH BRADYRHIZOBIUM SPP. UNDER MODERATE NITRATE LEVEL
}

\author{
Joaquim Albenísio Gomes da Silveira ${ }^{1 *}$; Roberto Cezar Lobo da Costa ${ }^{2}$;osé Tadeu Abreu Oliveira ${ }^{1}$ \\ ${ }^{1}$ Universidade Federal do Ceará - Laboratório Metabolismo e Fixação do Nitrogênio, Fortaleza, CE, Brasil. ${ }^{2}$ Faculdade de \\ Ciências Agrárias do Pará, Departamento de Biologia Vegetal e Fitossanidade, Belém, PA, Brasil
}

Submitted: February 14, 2000; Returned to authors for corrections: July 03, 2000; Approved: July 23, 2001

\begin{abstract}
This study was carried out to establish comparative effects of drought and recovery on the nitrate assimilation and nodule activity related to $\mathrm{N}_{2}$ fixation in cowpea plants [Vigna unguiculata $\mathrm{L}$. (Walp.)] previously inoculated with Bradyrhizobium spp. BR-3256 (CB-756) strain in the presence of $5 \mathrm{~mol} \mathrm{~m}^{-3} \mathrm{NO}_{3}^{-}$. Twenty-eight-day-old nodulated plants were submitted to water deprivation during 4 consecutive days and afterwards resupplied with nutrient solution during 2 days. The water deprivation caused a rapid increase in the nitrate content in root and a marked reduction in leaf nitrate reductase (NR) activity. In contrast nodule NR activity was slightly increased by water deprivation. Concomitantly, in nodules of water stressed plants, leghemoglobin and glutamine synthetase (GS) activity declined and a progressive reduction in ureide-N concentration in xylem sap was observed. Leaf-NR activity increased rapidly after rehydration while leaf nitrate content declined. In contrast both GS activity and soluble protein content in the nodule continued to decline in rewatered plants. In addition the concentration of leghemoglobin recovered well, while the xylem ureide- $\mathrm{N}$ content experienced a slight increase after rehydration. Despite the nitrate assimilation in leaves and the nodule activity had been both severely affected by water stress, the rapid recovery of nitrate reductase activity suggests that the nitrate assimilation process is less sensitive to drought/rehydration cycle when cowpea plants are nodulated in presence of moderate nitrate level.
\end{abstract}

Key words: glutamine synthetase, leghemoglobin, nitrate reductase, $\mathrm{N}_{2}$ fixation, water stress, Vigna unguiculata (L.) Walp

\section{INTRODUCTION}

Legumes are unique among higher plants able to use simultaneously or solely the sources of $\mathrm{NO}_{3}^{-}$from soil or fertilizer and $\mathrm{N}_{2}$ through symbiotic fixation in association with rhizobia (33). Nitrate constitutes the major source of inorganic nitrogen in cultivated soils. At high concentrations, nitrate inhibits both nodulation and $\mathrm{N}_{2}$ fixation in almost all-legume species. However, at low concentrations nitrate seems to favor the initial establishment of nodulated plants, as well as the plant growth in the reproductive phase, possibly acting as an additional source of nitrogen $(5,27)$. These relationships between nitrate and $\mathrm{N}_{2}$ fixation are well established in well-watered plants whereas under water stress conditions many questions remain unsolved, particularly at molecular level $(9,12,13,24)$.

Despite the relative tolerance of Vigna unguiculata to prolonged drought (12), particularly through increasing stomatal resistance and preservation of a not very low leaf water potential (7), has been reported that water stress has a significant effect on growth and biological $\mathrm{N}_{2}$ fixation $(12,13)$. Indeed, tropical legumes, including cowpea, seem to be more severely affected by water stress than temperate legumes (23). Some reports

\footnotetext{
* Corresponding author. Mailing addess: Universidade Federal do Ceará - Laboratório Metabolismo e Fixação do Nitrogênio (LABFIX), Caixa Postal 6020.60451-970 Fortaleza, CE, Brasil. Telefax: (+5585) 288-9821. E-mails: silveira@ufc.br, roblobo@amazon.com.br
} 
suggest that those legume species that close their stomata earlier in response to water stress are more sensitive to $\mathrm{N}_{2}$ fixation (31). On the other hand, the drought tolerance was inversely associate to ureide levels in xylem sap (24).

Nitrate reductase, NR (EC.1.6.6.1), is one of the most sensitive enzymes to water stress $(11,14)$. It catalyzes the $\mathrm{NO}_{3}^{-}$to $\mathrm{NO}_{2}^{-}$ reduction, considered the limiting step for conversion of nitrate$\mathrm{N}$ to amino acids and so for protein synthesis (11). As NR is a substrate inducible enzyme regulated by several metabolites, its mechanism of control during water stress seems complex due to involvement of direct and indirect factors (14). Water deficit induces an abrupt reduction in the uptake and nitrate flux rates from roots to leaves, preventing the mechanisms of NR protein synthesis-induction and NR activity (14). According to Ferrario-Méry et al. (11), tobacco plants transformed to express constitutive NR when submitted to water stress had initially an increase in NR degradation by proteases following by a decrease in the corresponding mRNA level three days later. These authors also observed that expression of the constitutive NR either temporarily delayed drought-induced loss of the NR activity or guaranteed a more rapid recovery of its activity after rehydration. On the other hand, legume root nodules might exhibit significant levels of constitutive type-NR unresponsive to nitrate $(1,5,27)$.

The importance and the physiological role of nitrate reduction inside of active nodules are still unknown, particularly under conditions of water stress. However, the nodule NR activity of alfalfa plants was shown to increase by effect of water stress both in the presence or in the absence of nitrate (1), whereas the nodule glutamine synthetase activity, when expressed on a protein basis, was relatively insensitive to mild water deficit in presence of high level of nitrate (2). It is possible that nodule NR may function under water stress in a dissimilatory mode to nitrate reduction $(1,24)$. Recently Figueiredo et al. (13) working on cowpea nodules submitted to progressive water stress pointed out that the glutamine synthetase activity (based on a fresh mass) was progressively reduced during soil drying. These authors concluded that GOGAT was more severely affected by water stress and best correlated with $\mathrm{N}_{2}$ fixation.

Under field conditions, cowpea plants exhibit a good tolerance to moderate levels of nitrate regarding to both nodulation and $\mathrm{N}_{2}$ fixation (9). Inoculation of cowpea with Bradyrhizobium strains alleviated the water stress as compared with uninoculated control (12). On the other hand, some evidences suggest that $\mathrm{N}_{2}$ fixation is more sensitive to drought than nitrate assimilation $(20,24)$. However, most of the published works were carried out with plants that were nodulated in the absence of $\mathrm{N}$ compared with those that received nitrate as the unique $\mathrm{N}$ source. In other experimental situation, plants were previously inoculated and, after a certain period of growth, they were divided into those that received a high nitrate level and those dependent only on $\mathrm{N}_{2}$ fixation $(1,24)$. Recently, we observed that $5 \mathrm{mM}$ nitrate increased water deficit tolerance in nodulated Vigna unguiculata plants inoculated with Bradyrhizobium spp. compared with plants inoculated in the absence of nitrate (9).

Reports on the simultaneous effects of drought upon nitrate assimilation and symbiotic $\mathrm{N}_{2}$ fixation in nodulated plants which had been previously adapted to a moderate nitrate level starting at germination onwards, simulating a field condition, are scarce. In this study, nodulated Vigna unguiculata plants grown in the presence of nitrate were submitted to water deprivation followed by recovery and then NR activity and parameters related to $\mathrm{N}$ assimilation from $\mathrm{N}_{2}$ fixation were compared to assess the relative sensitivity of these processes to water stress.

\section{MATERIALS AND METHODS}

\section{Plant Growth Conditions}

Vigna unguiculata L. (Walp.) cv. Vita 7 seeds, surface sterilized with $2.5 \%$ sodium hypochlorite solution were planted in the upper part of modified Leonard jars (27) containing a silica: vermiculite $(1: 2, \mathrm{v} / \mathrm{v})$ mixture previously sterilized in autoclave. The upper were then adjusted to lower part of the jars which were filled with $800 \mathrm{~mL}$ of $1 \mathrm{~mol} \mathrm{~m}^{-3} \mathrm{CaSO}_{4}$ solution. After two days, the roots were inoculated $\left(10^{9}\right.$ cells/plant $)$ with Bradyrhizobium spp. BR-3256 (CB-756) strain host legume Vigna unguiculata $\mathrm{L}$. Walp. origin Zimbabwe and supplied by EMBRAPA/CNPAB (National Agrobiology Research Centre), Rio de Janeiro, Brazil, and reinoculated four days later. The preparation of inoculants was described previously (21). A modified Hoagland and Arnon nutrient solution (27) containing $5 \mathrm{~mol} \mathrm{~m}^{-3} \mathrm{NO}_{3}^{-}$was used in place of $\mathrm{CaSO}_{4}$ onward and it was changed every two days. The $\mathrm{pH}$ of nutrient solution was maintained at $6.0 \pm 0.5$ with addition of $\mathrm{HCl}$ or $\mathrm{NaOH}$. The experiments were carried out in a greenhouse at means of temperature varying from $24^{\circ} \mathrm{C}$ (night) to $29^{\circ} \mathrm{C}$ (day). The average of relative humidity was $55 \%$ and photoperiod was $12 \mathrm{~h}$.

\section{Harvest and treatments}

Inoculated cowpea plants were grown in the nutrients containing $5 \mathrm{~mol} \mathrm{~m}^{-3} \mathrm{NO}_{3}^{-}$until 28 days after emergence. Next the plants were transferred to one of the following conditions of water availability: during 4 consecutive days, half of the plants received no irrigation (droughted plants) and the remaining ones received the nutrient solution (well-watered plants). After this period without irrigation, drought stressed plants were resupplied with nutrient solution during 2 days. A completely randomized design was employed. Six plants per lot were harvested at each day of water treatment and were separated in nodules, roots, stem and leaves, instantaneously frozen in liquid nitrogen and kept at $-20^{\circ} \mathrm{C}$ during 24 hours for later analysis. To determine nodule water content the organ fresh weights were recorded at each harvest 
and dry weights taken after drying at $80^{\circ} \mathrm{C}$. The leaf relative water content was measured according to Irigoyen et al., (18). Shoot and nodule dry weights were determined after drying at $70^{\circ} \mathrm{C}$ during $72 \mathrm{~h}$.

\section{In vivo nitrate reductase activity assay}

The anaerobic tissue slice method for determination of NR activity (E.C 1.6.6.1) in leaves was chosen because it showed an excellent correlation with the in situ nitrate reduction calculated by subtracting the total amount of both roots and shoots from the total nitrate uptake at each assay period in cowpea plants (30). Samples of $200 \mathrm{mg}$ of leaf discs $(7 \mathrm{~mm}$ diameter) or fresh nodule slices were placed in vials containing $5 \mathrm{~cm}^{3}$ of ice-cold incubation medium, consisting of $100 \mathrm{~mol} \mathrm{~m}^{-3}$ $\mathrm{K}$-phosphate buffer ( $\mathrm{pH} 7.5), 50 \mathrm{~mol} \mathrm{~m}^{-3} \mathrm{KNO}_{3}$ and $1 \%$ (v/v) isopropanol. Tissues were infiltrated by vacuum for $2 \mathrm{~min}$ at -67 $\mathrm{kPa}$, and then incubated in water in the dark for $30 \mathrm{~min}$ at $30^{\circ} \mathrm{C}$. After incubation, the concentration of nitrite released into the medium was determined by measuring absorbance at $540 \mathrm{~nm}$, as previously described (4).

\section{Glutamine Synthetase activity}

After blot drying, $1.0 \mathrm{~g}$ nodule samples were ground with liquid nitrogen in a chilled mortar with a pestle and extracted with $5 \mathrm{~cm}^{3}$ of $100 \mathrm{~mol} \mathrm{~m}^{-3} \mathrm{HEPES}$ buffer, $\mathrm{pH}$ 7.6, containing $5 \mathrm{~mol}$ $\mathrm{m}^{-3}$ dithiothreitol, $0.2 \mathrm{~mol} \mathrm{~m}^{-3}$ EDTA and $10 \mathrm{~mol} \mathrm{~m}^{-3} \mathrm{MgCl}_{2}$, at $0-4^{\circ} \mathrm{C}$, for $5 \mathrm{~min}$. The suspension was centrifuged at $30,000 \mathrm{~g}$, $2^{\circ} \mathrm{C}$, for $30 \mathrm{~min}$. GS activity in nodules was determined by hydroxamate biosynthetic method ("synthetase assay") previously described (10), with the following reaction mixture: $600 \mu \mathrm{L} 250 \mathrm{~mol} \mathrm{~m}^{-3}$. Tris-HCl buffer, pH 7.0;200 $\mu \mathrm{L} 300 \mathrm{~mol} \mathrm{~m}^{3}$ sodium glutamate $\mathrm{pH} 7.0 ; 200 \mu \mathrm{L} 30 \mathrm{~mol} \mathrm{~m}^{-3} \mathrm{ATP}, \mathrm{pH} 7.0 ; 200 \mu \mathrm{L}$ $500 \mathrm{~mol} \mathrm{~m}^{-3} \mathrm{MgSO}_{4} ; 200 \mu \mathrm{L} 1000 \mathrm{~mol} \mathrm{~m}^{-3}$ hydroxylamine hydrochloride neutralized with $1000 \mathrm{~mol} \mathrm{~m}^{-3} \mathrm{HCl}$ and $500 \mu \mathrm{L}$ of enzyme extract. This mixture was incubated at $30^{\circ} \mathrm{C}$ for 30 minutes and the concentration of the brown complex formed after the reaction of $\gamma$-glutamyl hydroxamate with $\mathrm{FeCl}_{3}$ determined by measuring absorbance at $540 \mathrm{~nm}$. In the control for each sample, hydroxylamine was omitted from the reaction mixture. The GS activity was expressed as mmol of $\gamma$-glutamyl hydroxamate (GHG)/hour/kg nodule dry mass.

\section{Ureide concentration in xylem sap}

Xylem exudate was collected from bleeding rootstocks after shoots had been decapitated through the hypocotyl region about $3 \mathrm{~cm}$ above the surface of the rooting medium (Minchin et al., 1980). The first droplets of the root-bleeding xylem sap were discarded. Subsequently collection continued for $1 \mathrm{~h}$ using a graduated syringe. The xylem sap collected was transferred immediately into ice-cooled glass vials and stored at $-20^{\circ} \mathrm{C}$. The ureide- $\mathrm{N}$ was determined by colorimetric method (34) based on the hydrolysis of alantoin and alantoic acid to glyoxylate.

\section{Determination of $\mathrm{NO}_{3}^{-}$, leghemoglobin and soluble protein}

Nitrate concentration in plant tissues was measured colorimetrically (8). Nodule leghemoglobin was extracted with Drabkin reagent and concentration determined by the cyanmethemoglobin method (35) using human hemoglobin as standard. Protein content of nodule extracts was determined according to Bradford (3), using bovine serum albumin as standard.

\section{RESULTS AND DISCUSSION}

\section{Effects of drought and rewatering on plant growth and nitrate assimilation}

Cessation of water irrigation caused a pronounced effect on the rate of cowpea shoot growth. After the first day of water deprivation, the increment of the plant shoot growth $(\mathrm{kg} \mathrm{DM}$ plant $^{-1}$ day $^{-1}$ ) was drastically reduced to zero, an effect that persisted during the drought period (Fig. 1A). As expected, decrease in the shoot growth rate was accompanied by a progressive decrease in the relative water content in the leaves (Fig. 1B). The same trend was observed for the nodule water content (Fig. 1C). These results indicate that the water deficit experienced by cowpea plants was severe in view of the fact that it was associated with values of high temperature and low relative humidity during the experimental period (see Materials and Methods). These results are expected since cowpea plants present typical responses of mesophytes plant species adapted to water deficit conditions, such as increment in the root growth, drastic reduction in the shoot growth associated with an increase in the stomatal resistance, maintenance of leaf water potential at levels not so low and high leaf water content $(7,9)$.

In opposition to the leaf response, the root growth was stimulated during the water deprivation period (9). Accordingly, after four days of dehydration the root dry matter was $36 \%$ higher than that of well-watered plants. Thus, root sink activity of stressed plants was preferentially stimulated in relation to that of leaf probably by a larger proportion of shoot-derived photosyntates utilized to promote a differentiated root growth. It is interesting to note that two days after rehydration the leaf dry mass increased around $47 \%$ whereas the root dry mass dropped $30 \%$ (data not shown). Withdrawal of water supply led to an abrupt fall in leaf NR activity of nodulated cowpea plants (Fig. 2A) along with a slight increase in nodule NR activity (Fig. $3 \mathrm{~A})$. At the first day of treatment leaf NR activity had already decreased to around $20 \%$ as compared to well-watered plants and continued to drop until day 4 when it amounted only $5 \%$. A distinct pattern of behavior, however, was observed in nodule NR activity (Fig. 3A). At days 2 and 3 it was slightly higher than those of well-watered plants but decreased to control values onward. Restoration of water supply led to a rapid recovery of the leaf NR activity to about $75 \%$ of well-watered plants after one day of rehydration (Fig. 2A), whereas the nodule NR activity was unchanged (Fig. 3A). 


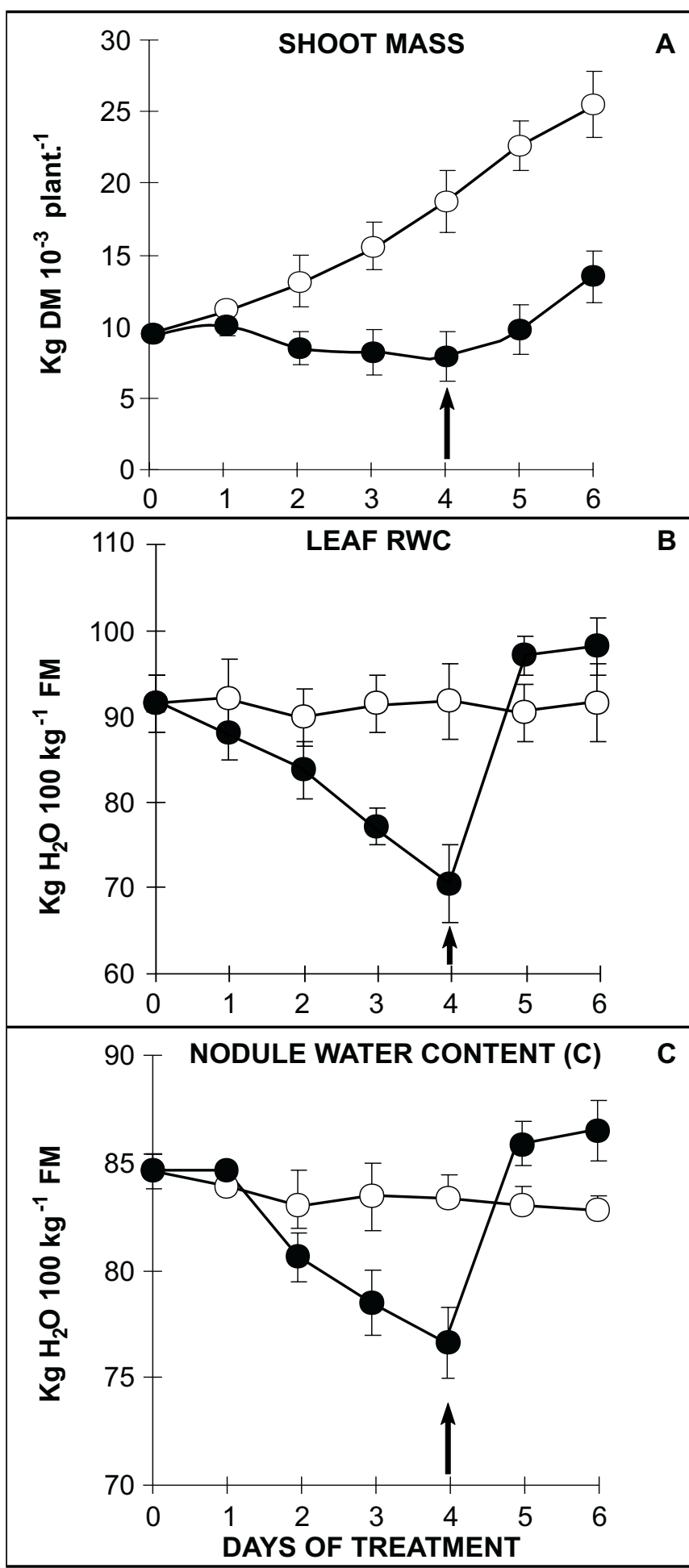

Figure 1. Shoot mass (A), Leaf Relative Water Content (B) and Nodule Water Content (C) in drought stressed (-๑) and well-watered cowpea plants $(\mathrm{O}-\mathrm{O})$. The arrow represents the onset of rehydration of stressed cowpea plants. Bars indicate standard deviation $(n=6)$.

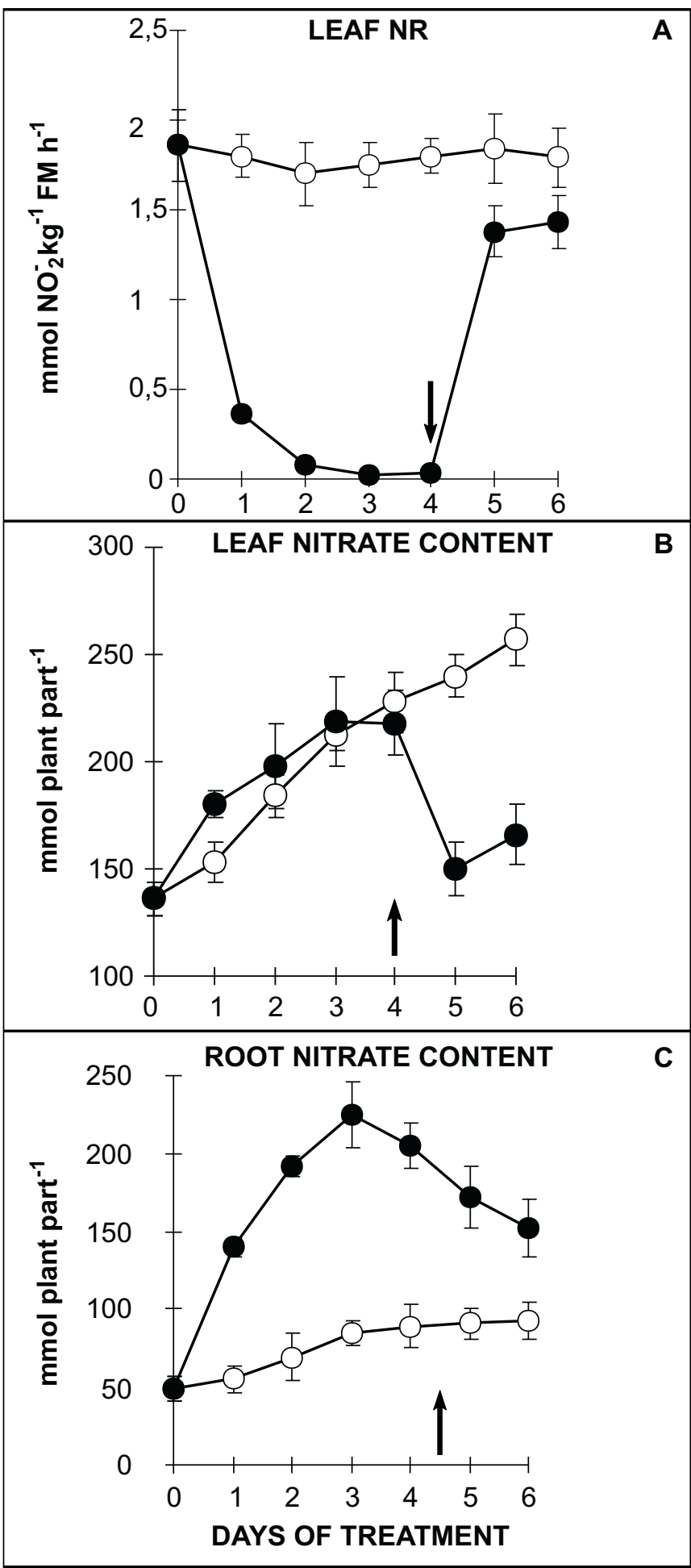

Figure 2. Leaf nitrate reductase activity (A), Leaf(B) and Root (C) nitrate content in drought stressed (-๑) and wellwatered cowpea plants $(\mathrm{O}-\mathrm{O})$. The arrow represents the onset of rehydration of stressed cowpea plants. Bars indicate standard deviation $(n=6)$. 


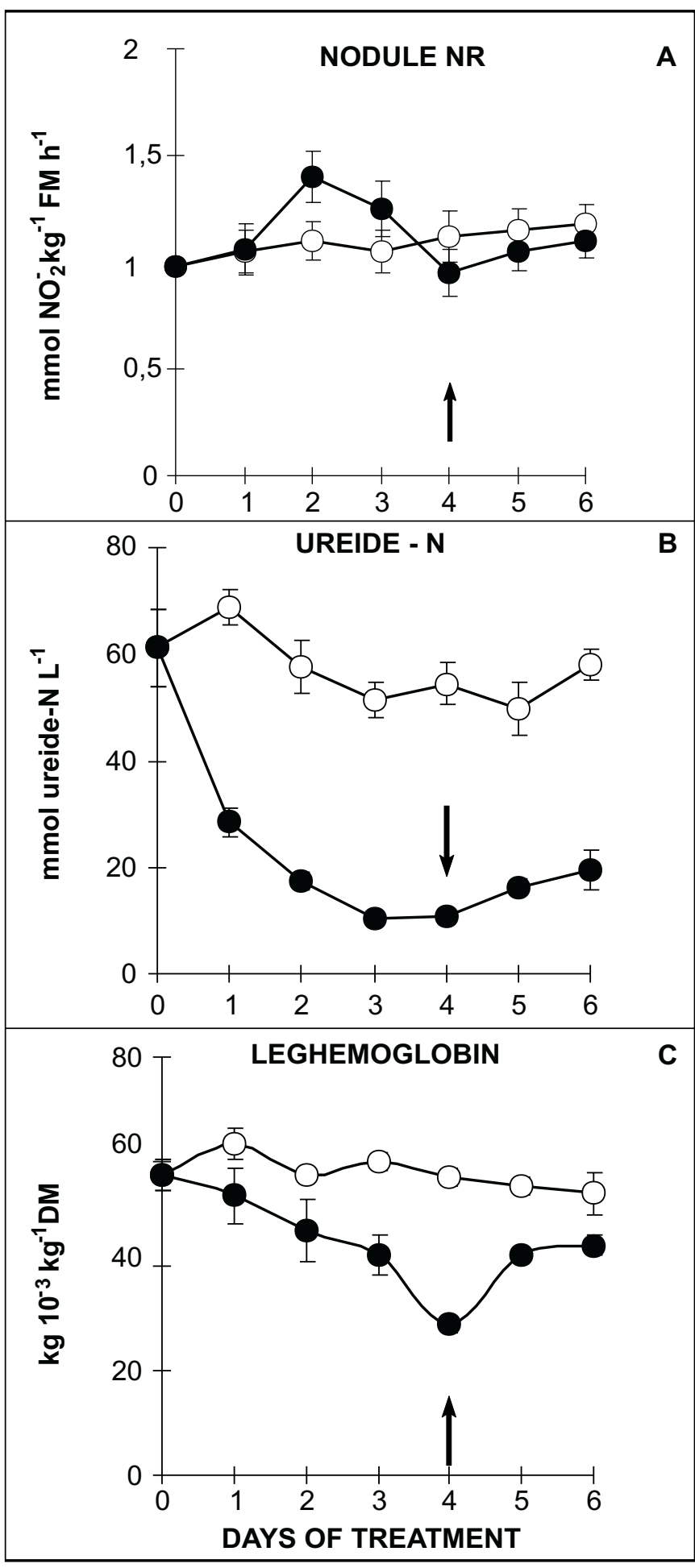

Figure 3. Nodule nitrate reductase activity (A), Ureide-N concentration in xylem sap (B) and leghemoglobin concentration $(\mathrm{C})$ in drought stressed $(\bullet-)$ ) and well-watered cowpea plants $(\mathrm{O}-\mathrm{O})$. The arrow represents the onset of rehydration of stressed cowpea plants. Bars indicate standard deviation $(n=6)$.
Under water deprivation the content of nitrate in root tissue increased steadily until day 3 as compared with well-watered plants (Fig. 2C). In the leaves, although $\mathrm{NO}_{3}^{-}$content had also increased it was similar to control plants until day 4 of water deprivation (Fig. 2C). Rehydration led to a rapid decrease in the nitrate content of leaf tissue whereas in the well-watered plants it progressively increased (Fig. 2B). The root $\mathrm{NO}_{3}^{-}$content decreased slowly after rehydration but remained higher than in control plants (Fig. 2C). The highest nitrate concentration observed in the leaves of stressed plants occurred due to the strong reduction in growth rate ("concentration effect") which was drastically affected by water deficit (data not shown). The total nitrate content in the shoot of stressed plants was not reduced as compared with well-watered plants (data not shown).

Despite the drastic decrease in nitrate flux from roots to leaves in xylem sap caused by water stress on cowpea plants (9) and the subsequent reduction in leaf NR activity, the relative nitrate accumulation observed in the leaves was not expected. Accordingly, Sinha and Nicholas (32), based on reports from several authors, attributed the increase in nitrate content to a drastic fall in NR activity that led to impaired leaf growth probably due to restriction on $\mathrm{N}$ compound synthesis. In the root tissue, on the other hand, nitrate accumulation was likely to be a response to the high rate of nitrate uptake owing to an increase in the $\mathrm{NO}_{3}^{-}$concentration surrounding the roots as a result of water deficit.

The results reported by Sinha and Nicholas (32) and our present study are in disagreement with those observed in maize plants (74), perennial $\mathrm{C}_{4}$ prairie-grasses (16), maize (14) and in tobacco plants (11). Nevertheless, the increase of leaf-nitrate content in water-stressed plants in parallel with a great diminution in NR activity is not easy to explain. However it is tempt to speculate that the highest nitrate concentration both in the root and in the external medium, associated with the presence of other ions, might have lead to the increase in the "root pressure" which in turn induced a nitrate flux to leaves mainly during periods of lower temperature and higher relative humidity when the leaf turgor had been partially recovery (data not shown). Indeed it is evident that transpiratory $\mathrm{NO}_{3}^{-}$flux to leaves in water-stressed plants was neither sufficient to maintain the NR stability and NR protein synthesis nor even protect NR enzyme from inhibitors and/or proteases (6).

The rapid and early loss of NR activity observed was most likely caused by NR denaturation/inactivation or degradation induced by water stress $(11,14)$ despite the presence of $\mathrm{NO}_{3}^{-}$ in leaf tissue. Presumably nitrate accumulation is restricted to the leaf vacuole as a storage pool (25) not contributing, consequently, for the metabolic nitrate pool (cytosolic). This latter is responsible for induction of NR synthesis, enzyme stability, and NR activity (6). Tobacco plants submitted to progressive water deprivation experienced a gradual decrease in leaf-NR activity in comparison to the corresponding mRNA 
which was much stable (11). The leaf NR activity from those plants exhibited a rapid and intense recovery after one day of plant rehydration. These authors postulated that drought initially causes an increase in NR protein breakdown and then accelerates degradation of the corresponding mRNA.

In this study, the rapid recovery of the leaf NR activity after plant rehydration with the nutrient solution (Fig. 2A) could be associated with an intense NR protein synthesis and to a rapid recovery of leaf turgor (data not shown). The severe decrease in the nitrate content both in leaf (Fig. 3A) and stem (data not shown), which occurred just after the plant rehydration, supports the idea that NR activity is strongly dependent on the plant-water flux $(11,14,32)$. Apparently, both the water deficit and nitrate flux into the leaf cell trigger a mechanism involving a molecular signaling leading to a switch on/switch off type control of leafNR activity. Similarly a decrease in leaf-NR activity was also observed in cowpea plants submitted to salt-osmotic shock (30).

In opposition to leaf NR response, the nodule NR activity of cowpea was slightly stimulated by water stress (Fig. 3A). The nodule NR activity of alfalfa plants also showed to increase by effect of water stress both in the presence or in the absence of nitrate (1), whereas the nodule glutamine synthetase activity, when expressed on a protein basis, was relatively insensitive to mild water deficit in presence of high level of nitrate (2). The importance and the physiological role of nitrate reduction inside of active nodules are still unknown particularly under conditions of water stress. It is possible that nodule NR may function under water stress in a dissimilatory mode to nitrate reduction $(1,24)$.

\section{Effects of drought and rewatering on parameters related to $\mathrm{N}_{2}$ symbiotic fixation}

The water deficit induced a significant decrease in the growth of cowpea nodule (Fig. 4A). During the 4 days of water stress, the nodule dry mass remained near to $0.5 \mathrm{~g} \mathrm{DM} /$ plant whereas in well-watered plants it changed from 0.5 to $1.1 \mathrm{~g} \mathrm{DM} /$ plant. After 2 days of rehydration, the rewatered plants exhibited only a slight recovery in nodule dry mass despite the significant recovery of the nodule water content (Fig. 1C). It is important to note that despite the presence of nitrate in the root medium, the nodule of well-watered control showed a growth rate (Fig. 4A) similar to that exhibited by the shoot (Fig. 1A), evidencing a possible adaptation of cowpea nodulated plants to utilize simultaneously and efficiently $\mathrm{NO}_{3}^{-}$and $\mathrm{N}_{2}$ fixation. Despite to leghemoglobin concentration, GS activity and ureide concentration in xylem sap had shown lower values when compared with nodulated plants cultivated in the absence of nitrate (9), they were compatible with the occurrence of active $\mathrm{N}_{2}$ fixation. Thus, in this present study the cowpea plants were able to use simultaneously the principal $\mathrm{N}$ sources mimicking field conditions.

The concentration of ureide- $\mathrm{N}$ in xylem sap was drastically reduced during the water-stress period (Fig. 3B) and did not

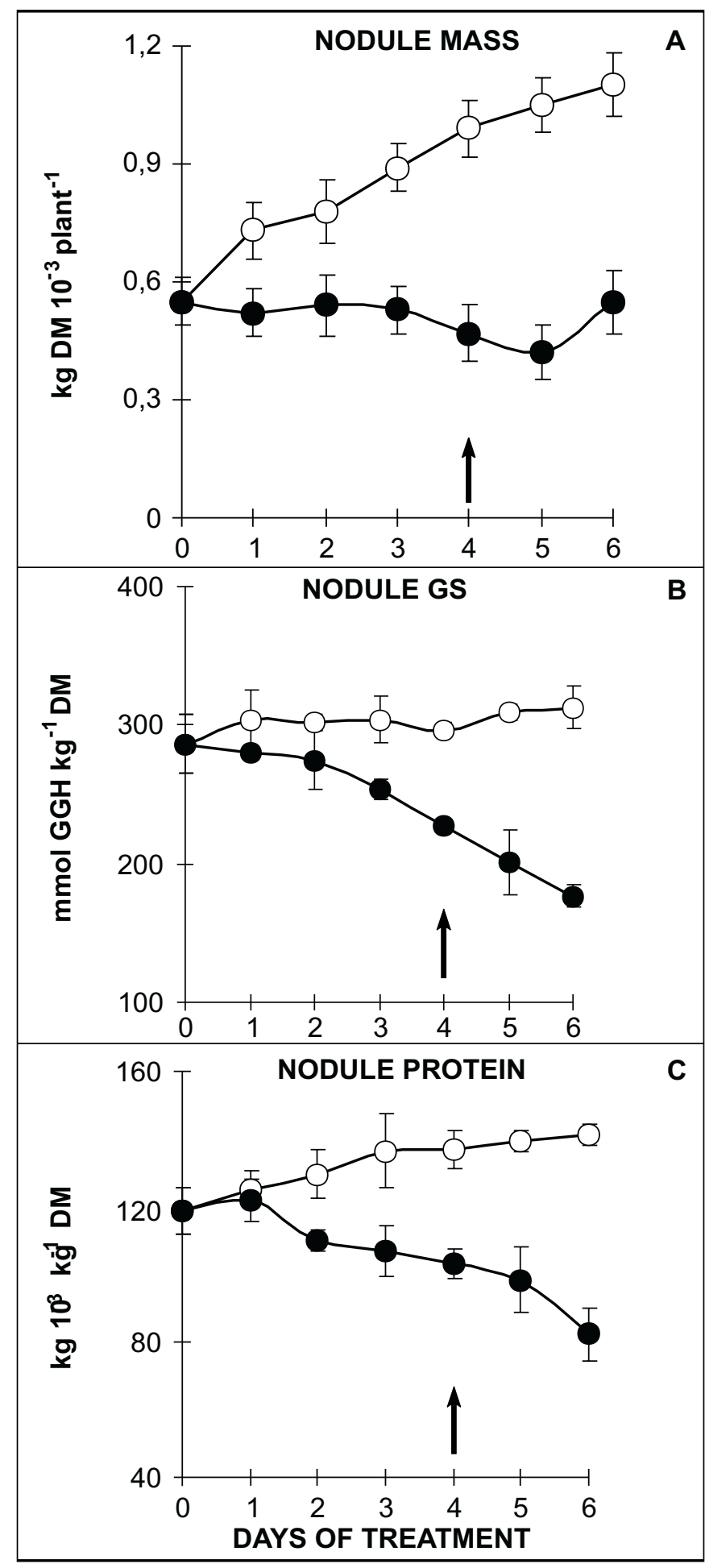

Figure 4. Nodule mass (A), glutamine synthetase activity (B) and soluble protein concentration (C) in drought stressed $(-)$ and well-watered cowpea plants $(\mathrm{O}-\mathrm{O})$. The arrow represents the onset of rehydration of stressed plants. Bars indicate standard deviation $(\mathrm{n}=6)$. 
recover to control values after rehydration. The decrease in nodule leghemoglobin concentration (Fig. 3C), although significant under water stress, was less pronounced and after rewatering reached values near to $80 \%$ of those of control plants. The nodule GS activity (Fig. 4B) decreased steadily across the 4 days of water stress in parallel to the decrease in the concentration of soluble proteins (Fig. 4C). Furthermore activity continued to drop, even after rehydration, to values that reached around $55 \%$ of those of control plants. These results strongly suggested that the process of symbiotic $\mathrm{N}_{2}$ fixation in cowpea plants was reduced under water stress. Similar adverse effects on symbiotic $\mathrm{N}_{2}$ fixation in other legume species have also been observed $(12,15,18)$.

When cowpea plants were subjected to different degrees of water stress (soil $\Psi_{\mathrm{m}}$ changing from -6.0 to below $-85 \mathrm{kPa}$ ), it was observed a low correlation between leghemoglobin concentration and nitrogenase activity (acetylene reduction) while the nitrogenase activity was highly correlated with the nodule water content (12). Analysis of ureide-N concentration in the xylem sap has been suggested as a efficient method for selection of the best symbiotic systems $(17,26)$. In cowpea plants submitted to water stress positive correlation between ureide- $\mathrm{N}$ concentration and both nitrogenase activity $\left(\mathrm{r}=0.86^{* *}\right)$ and total $\mathrm{N}\left(\mathrm{r}=0.80^{* *}\right)$ were observed, evidencing that the ureide- $\mathrm{N}$ concentration can indirectly measure plant dependence concerning $\mathrm{N}_{2}$ fixation under this condition (12). On the other hand, under well-watered conditions we had previously demonstrated that GS activity in root nodule correlates with $\mathrm{N}_{2}$ fixation in cowpea $(21,29)$, common bean (28), and soybean nodules (22).

When nodulated cowpea plants were totally dependent on symbiotic $\mathrm{N}_{2}$ they exhibited a higher sensitivity to elevated temperatures than nitrate-dependent plants (19). Our results are in agreement with those reported in a recent review by Serraj $e t$ al. (24), indicating that $\mathrm{N}_{2}$ fixation is more sensitive to drought than nitrate assimilation as demonstrated in studies carried out either in controlled growth conditions or in the field. Thus, in this study, both the $\mathrm{N}_{2}$ fixation, evaluated by ureide- $\mathrm{N}$ concentration, and nodule growth were severely affected during the period of water deprivation and showed a poor recovery after 2 days of rewatering. Accordingly, the specific leghemoglobin concentration and nodule GS activity (both based on protein content) of cowpea plants were less affected by water stress in contrast to ureide- $\mathrm{N}$ concentration and nodule growth. These results are similar to those recently reported for cowpea $(12,13)$.

It is interesting that apart from the $60 \%$ increase in nodule leghemoglobin concentration after 2 day of rehydration (Fig. 3C), total nodule protein (Fig. 4C) continued to decline whereas the ureide concentration exhibited a low recovery (Fig. 3B). Leghemoglobin concentration, expressed on the basis of soluble protein concentration, was higher in rewatered plants than in the well-watered ones. This result agrees with the patterns of nodule proteins observed on SDS-PAGE during water deprivation and after rewatering (9). Thus, after rehydration of nodulated cowpea plants the "de novo" synthesis of leghemoglobin isoforms seems to be favored over other nodulins. Thus, it is possible to speculate that the effect of water stress on the recovery of nodule activity and, particularly, on ureide production was more drastic than it was on NR activity in leaves of cowpea plants after rehydratation. Therefore further studies on the enzymes of ureide pathway are need to elucidate which biochemical steps are crucial for nodule activity recovery under water deprivation/rehydration cycle.

Although leaf-NR activity seemed to be more sensitive to water deprivation than were GS activity and leghemoglobin concentration in the nodules and ureide content in xylem sap, the rapid recovery of nitrate assimilation observed in leaves, following the recovery of plant growth, could represent an important way by which amino acids are supplied for protein synthesis after rehydratation of cowpea plants.

This study evidences that, despite the potential of nitrate assimilation in leaves and nodule activity had been both severely affected by water stress, the rapid recovery of leaf nitrate reductase activity suggests that the nitrate assimilation process is less sensitive to drought/rehydration cycle when cowpea plants are nodulated in presence of moderate nitrate level.

\section{ACKNOWLEDGEMENTS}

To Conselho Nacional de Desenvolvimento Científico e Tecnológico (CNPq), Financiadora de Estudos e Projetos (FINEP) and Fundação Cearense de Amparo à Pesquisa (FUNCAP) for financial support.

\section{RESUMO}

\section{Efeitos da deficiência hídrica e recuperação sobre a assimilação de nitrato e atividade de nódulos de plantas de caupi inoculadas com Bradyrhizobium spp. sob um nível moderado de nitrato}

Este estudo foi feito com a finalidade de estabelecer efeitos comparativos da seca e da reidratação na assimilação do nitrato e atividade do nódulo relacionado com a fixação de $\mathrm{N}_{2}$ em planta de caupi [Vigna unguiculata L. (Walp.)] previamente inoculada com Bradyrhizobium spp., estirpe BR-3256 (CB-756), na presença de $\mathrm{NO}_{3}^{-}\left(5 \mathrm{~mol} \mathrm{~m}^{-3}\right)$. Aos 28 dias após a emergência, as plantas noduladas foram submetidas à seca, durante 4 dias sucessivos e, depois, reidratadas com solução nutritiva durante 2 dias. A seca causou um aumento rápido no conteúdo de nitrato da raiz e uma acentuada redução na atividade da redutase do nitrato de folhas (NR). Em contraste, no nódulo esta atividade foi aumentada ligeiramente pelo déficit de água. Concomitantemente, nos nódulos das plantas estressadas, observou-se uma redução progressiva na concentração de leghemoglobina, atividade de 
glutamina sintetase (GS) e na concentração de ureídeos na seiva do xilema. A atividade da NR nas folhas aumentou rapidamente após a reidratação enquanto que o conteúdo de nitrato da mesma decresceu. Em contraste, a atividade de GS e a concentração de proteínas solúveis nos nódulos continuaram diminuindo nas plantas reidratadas. A concentração de leghemoglobina apresentou uma boa recuperação, enquanto que o conteúdo de ureídeos sofreu um leve aumento após a reidratação. Apesar da assimilação de nitrato em folhas e a atividade do nódulo terem sido severamente afetados pelo déficit de água, a rápida recuperação da atividade de redutase do nitrato nas folhas sugere que o primeiro processo seja menos susceptível ao ciclo de seca/ reidratação quando plantas de caupi são noduladas em presença de nível moderado de nitrato.

Palavras-chave: estresse hídrico, fixação de $\mathrm{N}_{2}$, glutamina sintetase, leghemoglobina, redutase do nitrato, Vigna unguiculata (L.) Walp

\section{REFERENCES}

1. Aparicio-Tejo, P.; Sánchez-Díaz, M. Nodule and leaf nitrate reductase and nitrogen fixation in Medicago sativa L. under water stress. Plant Physiol., 69:479-482, 1982.

2. Becana, M.; Aparicio-Tejo, P.; Sánchez-Díaz, M. Effects of water stress on enzymes of ammonia assimilation in root nodules of alfalfa (Medicago sativa). Physiol. Plant., 61:653-657, 1984.

3. Bradford, M.M. A rapid and sensitive method for the quantitation of microgram quantities of protein utilizing the principle of proteindye binding. Anal. Biochem., 722:248-254, 1973.

4. Brunetti, N.; Hageman, R.H. Comparison of in vivo and in vitro assays of nitrate reductase in wheat (Triticum aestivum L.) seedlings. Plant Physiol., 58:583-587, 1976.

5. Caba, J.M.; Iluch, C.; Legero, F. Distribution of nitrate reductase in Vicia faba: Effects of nitrate and plant genotype. Physiol. Plant., 93:667-672, 1995.

6. Campbell, W.H. Nitrate reductase structure, function and regulation: Bridging the Gap between Biochemistry and Physiology. Annu. Rev. Plant Physiol. Mol. Biol., 50:277-303, 1999.

7. Carvalho, M.H.C.; Laffray, D.; Louguet, D. Comparison of the physiological responses of Phaseolus vulgaris and Vigna unguiculata cultivars when submitted to drought conditions. Environ. Exp. Bot., 40(3):197-207, 1998

8. Cataldo, D.A.; Haroon, M.; Schrader, L.E.; Yougs, V.L. Rapid colorimetric determination of nitrate in plant tissue by nitration of salicylic acid. Comm. Soil Sci. and Plant Anal., 6(1):71-80, 1975.

9. Costa, R.C.L. Assimilação de nitrogênio e ajustamento osmótico de plantas noduladas de feijão-de-corda submetidas ao estresse hídrico, Tese de Doutorado, Universidade Federal do Ceará, 1999, 235p.

10. Farnden, K.L.F.; Robertson, J.G. Methods for studying enzymes involved in metabolism related to nitrogenase. In: Bergensen, J.F. (ed.): Methods of Evaluating Biological Nitrogen Fixation. Chichester, John Wiley and Sons, 265-316, 1980.

11. Ferrario-Méry, S.; Valadier, M.; Foyer, C.H. Overexpression of nitrate reductase in tobacco delays drought-induced decreases in nitrate reductase activity and mRNA. Plant Physiol., 117:293-302, 1998.

12. Figueiredo, M.V.B.; Vilar, J.J.; Burity, H.A.; De França, F.P. Alleviation of water stress effects in cowpea by Bradyrhizobium spp. inoculation. Plant Soil., 207(1):67-75, 1999a.

13. Figueiredo, M.V.B.; Burity, H.A.; De França, F.P. Drought stress response in enzymatic activities of cowpea nodules. J. Plant Physiol., $155: 262-268,1999 b$.
14. Foyer, C.H.; Valadier, M-H.; Migge, A.; Becker, T.W. Drought-induced effects on nitrate reductase activity and mRNA and on the coordination of nitrogen and carbon metabolism in maize leaves. Plant Physiol., 117:283-292, 1998.

15. Guerin, V.; Trinchant, J.C.; Rigaud, J. Nitrogen fixation $\left(\mathrm{C}_{2} \mathrm{H}_{2}\right.$ reduction) by broad bean (Vicia faba L.) nodules and bacteroids under water-restricted conditions. Plant Physiol., 92:595-601, 1990.

16. Heckathorn, S.A.; De Lucia, E.H.; Zielinski, R.E. The contribution of drought-related decreases in foliar nitrogen concentration to decreases in photosynthetic capacity during and after drought in prairie grasses. Physiol. Plant., 101:173-182, 1997.

17. Herridge, D.F.; Palmer, B.; Nurhayati, D.P.; Peoples, M.B. Evaluation of the xylem ureide method for measuring $\mathrm{N}_{2}$ fixation in six tree legume species. Soil Biol. Biochem., 28:281-289, 1996.

18. Irigoyen, J.J.; Emerich, D.W.; Sánchez-Díaz, M. Water stress induced changes in concentrations of proline and total soluble sugars in nodulated alfafa (Medicago sativa) plants. Physiol. Plant., 84:55-60, 1992.

19. Minchin, F.R.; Summerfield, R.J.; Neves, M.C.P. Carbon metabolism, nitrogen assimilation and seed yield of cowpea (Vigna unguiculata L.) grown in an adverse temperature regime. J. Exp. Bot., 31:13271345,1980 .

20. Purcell, L.C.; King, C.A. Drought and nitrogen source effects on nitrogen nutrition, seed growth, and yield in soybean. J. Plant Nutr., 19:969-993,1996.

21. Rodrigues, J.L.M.; Melloto, M.; Silveira, J.A.G. Nodulin activities, hydrogenase expression and nitrogen fixation in cowpea inoculated with $\mathrm{Hup}^{+}$and Hup symbionts. Braz. J. Plant Physiol., 10(2):85-90, $1998 \mathrm{a}$.

22. Rodrigues, J.L.M.; Melloto, M.; Oliveira, J.T.A.; Silveira, J.A.G. Efficiency of soybean nodules in relation to nodulin activities and hydrogenase expression. Braz. J. Plant Physiol., 10(3):173-78, 1998b.

23. Serraj, R.; Sinclair, T.R. Processes contributing to $\mathrm{N}_{2}$ fixation insensitivity to drought in the soybean cultivar Jackson. Crop Sci., 36:961-968, 1996

24. Serraj, R.; Sinclair, T.R.; Purcell, L.C. Symbiotic $\mathrm{N}_{2}$ fixation response to drought. J. Exp. Bot., 50(331):143-155, 1999.

25. Shaner, D.L.; Boyer, J.S. Nitrate reductase activity in maize (Zea mays L.) leaves. I. Regulation by nitrate flux. Plant Physiol., 58:499504, 1974.

26. Silva, M. de; Purcell, L.C.; King, A. Soybean petiole ureide response to water deficits and decreased transpiration. Crop Sci., 36:611616, 1996.

27. Silveira, J.A.G.; Matos, J.C.S.; Ceccato, V.M.; Sampaio, A.H.; Costa, R.C.L. Induction of reductase nitrate activity and nitrogen fixation in two Phaseolus species in relation to exogenous nitrate level. Physiol. Mol. Biol. Plant., 4:81-188, 1998a.

28. Silveira, J.A.G.; Contado, J.L.; Rodrigues, J.L.M.; Oliveira, J.T.A Nodulin activities in relation to nodule development and nitrogen fixation in common beans (Pheseolus vulgaris L.). Physiol. Mol. Biol. Plants, 5:238-49, 1999a.

29. Silveira, J.A.G.; Contado, J.L.; Rodrigues, J.L.M.; Oliveira, J.T.A. Phosphoenolpyruvate Carboxylase and Glutamine Synthetase Activities in Relation to Nitrogen Fixation in Cowpea Nodules. Braz. J. Plant Physiol., 10(1):9-23, 1998 b.

30. Silveira, J.A.G.; Melo, A.R.B.; Viégas, R.A. Salt-induced decrease on nitrate uptake and assimilation in cowpea plants. Braz. J. Plant Physiol., 11(2):423-35, 1999b.

31. Sinclair, T.R.; Serraj, R. Dinitrogen fixation sensitivity to drought among grain legume species. Nature, 378-344, 1995.

32. Sinha, S.K.; Nicholas, D.J.D. Nitrate Reductase. In: The Physiology and Biochemistry of Drought Resistance in Plants. Eds. L G Paleg \& D Aspinall. Academic Press, Sydney, 1981, pp. 145-169.

33. Vessey, J.K.; Waterer, J. In search of the mechanisms of nitrate inhibition of nitrogenase activity in legume nodule: Recent developments. Physiol. Plant., 81:171-176, 1992.

34. Vogels, G.D.; Van Der Drift, C. Differential analyses of glyoxilate derivatives. Anal. Biochem., 33:143-157, 1970.

35. Wilson, D.O.; Reisenauer, H.M. Determination of leghemoglobin in legume nodules. Anal. Biochem., 6:27-30, 1963. 